\title{
Second European Pond Workshop: Conservation of pond biodiversity in a changing European landscape
}

\author{
P. Nicolet ${ }^{1 *}$, A. Ruggiero ${ }^{2}$, J. Biggs ${ }^{1}$ \\ ${ }^{1}$ Pond Conservation: The Water Habitats Trust, c/o Oxford Brookes University, Gipsy Lane, Oxford OX3 OBP U.K. \\ ${ }^{2}$ Dipartimento di Biologia, Università degli Studi di Roma “Tor Vergata”, Via della Ricerca Scientifica 00133 Roma Italy.
}

A meeting held in Toulouse, France, from $23^{\text {rd }}$ to $25^{\text {th }}$ February 2006 and co-organised by the University Paul Sabatier Toulouse III \& CNRS (France), Pôle Relais Mares et Mouillères de France (France), University of Applied Sciences of Western Switzerland (Switzerland), University of Geneva (Switzerland), Pond Conservation (UK), University of Leuven (Belgium).

Keywords: ponds, biodiversity, management, land-use, EPCN

\section{The value of ponds}

Recent years have seen an increased awareness of the importance of ponds for biodiversity and of their vulnerability to environmental degradation. The term 'pond' includes a wide range of standing freshwater bodies of varying sizes and with a variety of hydroperiod characteristics (c.f. for reviews Biggs et al. 2005, Søndergaard et al. 2005). Ponds can either be man-made or natural in origin, and occur in all biogeographical regions, including semi-arid and arid areas (e.g. Frisch et al. 2006). They are often found in clusters, forming a network of patches or 'pondscape' (Boothby 1997). These are particularly common on floodplains, but ponds can also occur naturally at high densities in other types of landscapes, such as high altitude zones in the Alps (Oertli et al. 2007).

Ponds have many functions relating to biodiversity, paleoecology, archaeology, education, recreation, economy, hydrology, culture and aesthetics (Oertli et al. 2005). They tend to be ubiquitous, and occur even in more urbanised areas, providing a link between wildlife and people. Ponds are also increasingly being used as experimental systems to test ecological theories (De Meester et al. 2005)

The high biodiversity value of ponds is now well established, and particularly their importance for a wide range of rare and endangered species, including amphibians, many invertebrates (such as dragonflies, water beetles and temporary pond macro-crustaceans), and aqua-

*Corresponding author: pnicolet@brookes.ac.uk tic plants (e.g. Grillas et al. 2004, Scheffer et al. 2006). However, ponds are also an important habitat for more common species, some with increasingly threatened populations. A recent review of habitat preferences of aquatic fauna and flora demonstrated that most species are potential inhabitants of ponds, with a significant proportion only ever found in this habitat type (Oertli et al. 2004). In the intensively farmed landscapes which cover some $80 \%$ of the European land mass, ponds also play a vital role as biodiversity 'hotspots', as refuges for both terrestrial and aquatic organisms, and as 'stepping stone' habitats (European Communities 1994). Recent research has also shown that, remarkably, these small waterbodies contribute as much to the regional 'species pool' as rivers or lakes (Williams et al. 2004).

\section{Threats and opportunities}

Unfortunately, ponds face many threats as a result of agricultural intensification, development, over-abstraction of water for human use, land drainage, inappropriate management and, potentially, climate change (e.g. Bronmark \& Hansson 2002, Biggs et al. 2005, Declerck et al. 2006). Although still abundant in many European countries, the number of ponds has declined dramatically over the past century (Hull 1997). This is further exacerbated by the fact that (i) pond creation, either as part of natural processes or human activity, is not compensating for losses, and (ii) the intensity of natural pond creation processes has been highly reduced through anthropogenic activities (e.g. river regulation). 
Their relatively small size and volume compared to rivers and lakes can be both an advantage and a disadvantage. On one hand, ponds are particularly vulnerable to degradation, and can provide an early warning system for environmental changes (De Meester et al. 2005, Oertli et al.2007). On the other hand, they can be easily created at low cost for maximum conservation benefits by using simple design principles (Williams et al.2007). Their catchments also tend to be relatively small, and can be more readily protected than entire lake, river or even stream systems (Davies et al. 2006).

These characteristics, low cost of creation and high biodiversity value, means that ponds can also play a valuable role in enhancing aquatic biodiversity at a landscape scale. They can be strategically sited to create links, or stepping stones, between existing aquatic habitats, in locations where minimal environmental degradation occurs. Conversely, ponds can be sited in isolated areas, providing new habitats and encouraging different types of aquatic communities.

\section{The European Pond Conservation Network (EPCN)}

Despite the recent increase in awareness of the importance of ponds for biodiversity and society, and of their vulnerability to environmental degradation, legislative protection of ponds is still inadequate. Indeed, only one type of pond is listed as a priority habitat type in the Habitats Directive (Mediterranean temporary ponds) ${ }^{* *}$. The other major piece of legislation which could benefit ponds, The Water Framework Directive (WFD), which is intended to protect all waters, will also have little effect on ponds. This is because most national administrations have set a 50 ha size limit to the waterbodies to which WFD will apply. Therefore Europe's most powerful piece of water legislation, as currently being implemented, will bring little or no benefits for critically important ponds.

However, some European countries have begun to develop elements of a national strategy for pond conservation and smaller scale initiatives, often linked to the general public, are abundant in many regions (e.g. UK and France). There is now a need to strengthen, develop and coordinate existing activities, and to build a common framework in order to establish a sound scientific

\footnotetext{
** Several other priority habitat types (e.g. turloughs in Ireland, natural eutrophic lakes) theoretically include waterbodies less than 5 ha in area. In practice, these priority habitats were established to protect lakes, and the ponds which might fit these categories are often largely ignored.
}

and practical basis for pond conservation in Europe. The European Pond Conservation Network (EPCN) was established to address these issues. Conceptually, the network is filling the gap left by virtually all other water and conservation agencies in Europe.

The European Pond Conservation Network (EPCN, www.epcn.org) was established at the First European Pond Workshop in Geneva, in October 2004. The mission of the Network is to promote the awareness, understanding and conservation of ponds in a changing European landscape. Specifically, the Network has five objectives:

1. To exchange information on pond ecology and conservation between researchers, managers and practitioners.

2. To promote understanding of pond ecology by encouraging the development and coordination of fundamental and applied research.

3. To raise the profile of ponds and guide national and supra-national policies for their protection.

4. To promote effective practical pond conservation.

5. To disseminate information to the public on the importance, attractiveness and conservation of ponds.

Although in its infancy, the EPCN includes representatives from most European countries and is now developing its range of activities to encourage links between researchers and practitioners, and with other national and international nature conservation organisations with an interest in small waterbodies (e.g. Ramsar Convention).

\section{Overview of contributions to this special issue}

\section{The 2nd European Pond Workshop}

The 2nd European Pond Workshop devoted to the "Conservation of pond biodiversity in a changing European landscape" was based on three topics: (i) understanding pond ecology, (ii) added value of ponds, and (iii) pond management. In total, the workshop had some 60 participants, from 12 countries (Austria, Belgium, Denmark, France, Germany, Hungary, Ireland, Italy, Poland, Spain, Switzerland and the UK) who attended the plenary sessions and three working group meetings: (i) Pond Manifesto, (ii) EPCN Funding and (iii) Activities and Joint Research Programs. Close to 120 authors contributed oral $(n=27)$ and poster $(n=29)$ presentations which made the workshop a success. 
As a result of the First European Pond Workshop, two special issues covering many aspects of pond ecology and conservation were prepared and published in 2004 and 2005 (Aquatic Conservation: Marine and Freshwater Ecosystems volume 15 issue 6, and Archives des Sciences volume 57 issues 2-3). This volume, together with a Hydrobiologia special issue to be published in 2007, will be published as a result of the $2^{\text {nd }}$ European Pond Workshop.

\section{Selected papers}

The impact of human activities on water quality and the hydrological regime of freshwater systems is an especially important issue in highly populated regions. This problem is of particular concern in arid and semiarid areas, where wetlands in general and ponds in particular are being lost. Accordingly, research efforts are being increasingly focused on these waterbodies, in order to promote their creation, restoration and to develop appropriate management guidelines. Three papers selected for this special issue focus on ponds located in the Mediterranean region along the coasts of Italy and Spain.

In the first of these studies, Relationships between the presence of odonate species and environmental characteristics in lowland ponds of central Italy, the authors showed that Odonata species preferred low nutrient (nitrogen) conditions among permanent and temporary ponds located along the Tyrrhenian coast in Central Italy. Here the last remnants of original Mediterranean lowland forest are impacted by the surrounding urban and agricultural landuse and nutrient pollution is likely to be a serious threat to local wetlands. The length of the wet period and macrophyte community structure were both factors correlated with the richness of Odonata species living in ponds. Odonata are predators which utilise both aquatic and terrestrial habitats, which makes them intimately linked to the structure and function of the biotopes in which they live. These findings on the relationships between Odonata and their environment are particularly important for monitoring coastal wetlands, as shown by studies of similar systems in Kenya (Clausnitzer 2003).

In the study entitled Benthic diatom communities and their relationship to water variables in wetlands of central Italy, the authors investigated the potential for benthic diatoms to be used as bioindicators to assess the ecological quality of Mediterranean wetland systems. Despite the relatively scarce number of pond types (i.e. streams, coastal ponds, freshwater pond), a total of 225 species and varieties belonging to 54 genera were collected. Waterbody assemblage compo- sition was mainly related to nutrient and chloride concentrations. The study also compared the performance of various indices currently used for assessing the quality of flowing waters. These results illustrated the potential for the use of benthic algae as bioindicators for water quality assessment in small waterbodies.

In Macroinvertebrate communities in sediment and plants in coastal Mediterranean water bodies (Central Iberian Peninsula) the authors reported data on the macroinvertebrate assemblages of six ponds located in a wetland area along the Mediterranean coast of Spain. Samples collected from sediments and aquatic macrophytes contained 70 invertebrate taxa, including endemic species and taxa with a restricted distribution were found. The study thus confirms the important role that ponds, and wetlands in general, play in maintaining freshwater biodiversity. This paper also highlighted the potential contribution of ponds in landscape scale restoration schemes as a source for the re-colonisation of wetland habitats.

The importance of ponds for the biodiversity of several freshwater taxa is well recognized (Oertli et al. 2002, Williams et al. 2004), and this is the subject of the other two papers selected for this special issue. In the short note entitled A rapid survey of large branchiopods in Romania, the author reported the results of a two year survey which focussed exclusively on the presence of branchiopods and was carried out in over 670 ephemeral pools in Romania. He recorded a total of 15 species, representing $56 \%$ of the branchiopod species reported for this country. Three species found in this survey were collected in Romania for the first time. As branchiopods represent an important flagship group for temporary wetlands in general, this group can be used to assess the value of wetlands in a specific area. This paper suggested that this group of invertebrates could be used in situations where time is necessarily limited (i.e. in rapid assessment protocols).

In Monitoring status, habitat features and amphibian species richness of Crested newt (Triturus cristatus superspecies) ponds at the edge of the species range (Salzburg, Austria) the authors reported the results of a survey and monitoring programme on the distribution of Triturus cristatus superspecies in the province of Salzburg. Historical data on newt presence were analysed in conjunction with those collected during the current study. The results showed that many ponds which historically supported T. cristatus no longer existed. The authors also discussed the possible habitat requirements at regional level for the effective conservation and management of threatened species. The progressive disappearance or/and alteration of ponds may be 
considered one of the major problems causing the continued decline of amphibian populations in the world (Alford \& Richards 1999, Dodd \& Smith 2003). This is particularly evident in the highly urbanised countries of Central and Western Europe where the functioning of natural pond networks is obviously compromised. This is also the one of the main reason why ponds are created and restored in several countries. For example, about 700 small lakes and ponds are now created yearly in Denmark (Danish Forest and Nature Agency 2002 in Søndergaard et al. 2005). The need for acquiring scientific knowledge for effective guidelines is thus evident and highlights the importance of the present contribution.

\section{Future and conclusions}

A wide range of issues related to the conservation of small freshwater bodies are included in this special issue, reflecting the diversity of interests represented in the $2^{\text {nd }}$ European Pond Workshop. The European Pond Conservation Network (EPCN) is now continuing to develop its activities with the organisation of a $3^{\text {rd }}$ Pond Workshop scheduled to take place in spring 2008 in Barcelona. This meeting is likely to focus on ponds in the Mediterranean region, and in particular temporary ponds, and on the perennial problem of pond management, a subject which has been relatively little researched to date. This next workshop will also aim to promote the effective communication and collaboration between practitioners and researchers.

\section{Acknowledgements}

We wish to thank the sponsors of the 2nd European Pond Workshop (CNRS, University Paul Sabatier, Laboratoire d'Ecologie des Hydrosystèmes UMR 5177, Région Midi-Pyrénées, Conseil Général de la Haute-Garonne, French Water Agency).

\section{References}

Alford R.A. \& Richards S.J. 1999. - Global amphibian declines: a problem in applied ecology. Annu. Rev. Ecol. Syst., 30,133-65.

Biggs J., Williams P., Whitfield M., Nicolet P. \& Weatherby A. 2005. - 15 Years of Pond Assessment in Britain: results and lesson learned from the work of Pond Conservation. Aquat. Conserv. Mar. Freshwat. Ecosyst., 15, 693-714.

Boothby J. 1997. - Pond conservation: towards a delineation of pondscape. Aquat. Conserv. Mar. Freshwat. Ecosyst., 7, 127-132.

Bronmark C. \& Hansson L.A. 2005. - Environmental issues in lakes and ponds: current state and perspectives. Environ. Conserv., 29, 290-307.

Clausnitzer V. 2003. - Dragonfly communities in coastal habitats of Kenya: indication of biotope quality and the need of conservation measures. Biodiv. Conserv., 12, 333-356.

Davies B.R., Biggs J. \& Williams P. 2006. - Towards achieving sustainability for the biodiversity of aquatic habitats in UK agricultural landscapes. In Davies B. R. \& Thompson S. (eds) 2006. Water and the landscape: the Lanscape Ecology of Freshwater Ecosystems, Proceedings of the fourteenth annual IALE(UK) conference, Oxford Brookes University.
Declerck S., De Bie T., Ercken D., Hampel H., Schrijvers S., VanWichelen J., Gillard V., Mandiki R., Losson B., Bauwens D., Keijers S., Vyverman W., Goddeeris B., De Meester L., Brendonck L. \& Martens K. 2006. - Ecological characteristics of small farmland ponds: Associations with land use practices at multiple spatial scales. Biol. Conserv., 131, 523-532.

De Meester L., Declerck S., Stoks R., Louette G., Van de Meutter F., De Bie T., Michels E. \& Brendonck L. 2005. - Ponds and pools as model systems in conservation biology, ecology and evolutionary biology. Aquat. Conserv. Mar. Freshwat. Ecosyst., 15, 715-725.

Dodd C.K. \& Smith L.L. 2003. - Habitat destruction and alteration: historical trends and future prospects for amphibians. In Amphibian Conservation, Semlitsch RD (ed.). Smithsonian Institution, Washington; 94-112

European Communities 1994. - Council Directive 92/43/EEC of 12 May 1992 on the conservation of natural habitats and of wild fauna and flora, Article 10. Office for Official Publications of the European Communities.

Frisch D., Moreno-Ostos E. \& Green A.J 2006. - Species richness and distribution of copepods and cladocerans and their relation to hydroperiod and other environmental variables in Donana, southwest Spain. Hydrobiologia 556, 327-340.

Grillas P., Gauthier P., Yavercovski N. \& Perennou C. 2004. Mediterranean temporary pools. Vol. 1 Issues relating to conservation, functionnning and management. Station Biologique de La Tour du Valat Ed. 118p.

Hull A. 1997. - The pond life project: a model for conservation and sustainability. In: British Pond Landscape, Proceedings from the UK conference of the Pond Life Project (Ed. by Boothby J.), pp. 101-109. Liverpool: Pond Life Project.

Oertli B., Joye D.A., Castella E., Juge R., Cambin D. \& Lachavanne J.-B. 2002. - Does size matter? The relationship between pond area and biodiversity. Biol. Conserv. 104, 59-70.

Oertli B. Auderset-Joye D., Indermuehle N., Juge R. \& Lachavanne J.-B. 2004. $1^{\text {st }}$ European Workshop: conservation and monitoring of pond biodiversity. Archiv. Sci., 57, 2-3.

Oertli B., Biggs J., Cereghino R., Grillas P., Joly P. \& Lachavanne J.B. 2005. - Conservation and Monitoring of Pond Biodiversity : introduction. Aquat. Conserv. Mar. Freshwat. Ecosyst., 15, 535-540.

Oertli B., Indermuehle N., Angélibert S., Hinden H. \& Stoll A. 2007. - Macroinvertebrate assemblages in 25 high alpine ponds of the Swiss National Park (Cirque of Macun) and relation to environmental variables. Hydrobiologia, in press.

Scheffer M., Zimmer K., Jeppesen E., Butler M.G., van Geest G.J., Hanson M.A., Søndergaard M., Declerck S., De Meester L. 2006. - Small biotope size and isolation can promote species richness: second-order effects on biodiversity in shallow lakes and ponds. Oikos, 112, 227-231.

Søndergaard M., Jeppesen E., Jensen J.P. 2005. - Pond or lake: does it make any difference? Archiv. Hydrobiol., 162, 143-165.

Williams P., Whitfield M., Biggs J., Bray S., Fox G., Nicolet P. \& Sear D.A. 2004. - Comparative biodiversity of rivers, streams, ditches and ponds in an agricultural landscape in Southern England. Biol. Conserv., 115, 329-341.

Williams P., Whitfield M., Biggs J. 2007. - How can we make biodiverse new ponds? A case study monitored over seven years. Hydrobiologia, in press. 